\title{
Connecting Urban Food Plans to the Countryside: Leveraging Denver's Food Vision to Explore Meaningful Rural-Urban Linkages
}

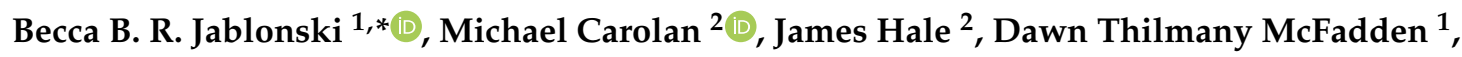 \\ Erin Love ${ }^{1}$, Libby Christensen ${ }^{3}$, Tabitha Covey ${ }^{4}{ }^{(0}$, Laura Bellows ${ }^{5}{ }^{\circ}$, Rebecca Cleary ${ }^{1}$, \\ Olaf David ${ }^{6}$, Kevin E. Jablonski ${ }^{7}$, Andrew S. Jones ${ }^{8}\left(\mathbb{D}\right.$, Paul Meiman ${ }^{7}$, Jason Quinn ${ }^{9}$, \\ Elizabeth P. Ryan ${ }^{10}$, Meagan Schipanski ${ }^{11}$, Hailey Summers ${ }^{9}$ and Mark Uchanski ${ }^{4}$ \\ 1 Department of Agricultural and Resource Economics, Colorado State University, Fort Collins, CO 80523, \\ USA; Dawn.Thilmany@ColoState.edu (D.T.M.); ealove@rams.colostate.edu (E.L.); \\ Rebecca.Cleary@colostate.edu (R.C.) \\ 2 Department of Sociology, Colorado State University, Fort Collins, CO 80523, USA; \\ Michael.Carolan@colostate.edu (M.C.); jameswhalephd@gmail.com (J.H.) \\ 3 Routt County Extension, Colorado State University, Steamboat Springs, CO 80477, USA; \\ lchristensen@co.routt.co.us \\ 4 Department of Horticulture and Landscape Architecture, Colorado State University, Fort Collins, CO 80523, \\ USA; Tabitha.Covey@colostate.edu (T.C.); Mark.Uchanski@colostate.edu (M.U.) \\ 5 Department of Food Science and Human Nutrition, Colorado State University, Fort Collins, CO 80523, USA; \\ Laura.Bellows@colostate.edu \\ 6 Department of Civil and Environmental Engineering, Colorado State University, Fort Collins, CO 80523, \\ USA; odavid@colostate.edu \\ 7 Department of Forest and Rangeland Stewardship, Colorado State University, Fort Collins, CO 80523, USA; \\ kevin.jablonski@colostate.edu (K.E.J.); Paul.Meiman@colostate.edu (P.M.) \\ 8 Cooperative Institute for Research in the Atmosphere, Colorado State University, Fort Collins, CO 80523, \\ USA; Andrew.S.Jones@colostate.edu \\ 9 Department of Mechanical Engineering, Colorado State University, Fort Collins, CO 80523, USA; \\ Jason.Quinn@colostate.edu (J.Q.); haileysummers725@gmail.com (H.S.) \\ 10 Department of Environmental and Radiological Health Sciences, Colorado State University, Fort Collins, \\ CO 80523, USA; E.P.Ryan@colostate.edu \\ 11 Department of Soil and Crop Sciences, Colorado State University, Fort Collins, CO 80523, USA; \\ Meagan.Schipanski@colostate.edu \\ * Correspondence: Becca.Jablonski@colostate.edu
}

Received: 4 February 2019; Accepted: 26 March 2019; Published: 4 April 2019

check for updates

\begin{abstract}
Cities are increasingly turning to food policy plans to support goals related to food access, food security, the environment, and economic development. This paper investigates ways that rural farmers, communities, and economies can both support and be supported by metropolitan food-focused initiatives. Specifically, our research question asked what opportunities and barriers exist to developing food policies that support urban food goals, particularly related to local procurement, as well as rural economic development. To address this question, we described and analyzed a meeting of urban stakeholders and larger-scale rural producers related to Colorado's Denver Food Vision and Plan. We documented and explored "findings" gleaned from a supply chain diagraming and data compilation process that were then used to inform an event that brought together diverse supply chain partners. Three findings stand out. First, facilitating dialog between urban food policymakers and rural producers to understand potential tensions, mitigate such tensions, and capitalize on opportunities is essential. Second, perceptions and expectations surrounding "good food" are nuanced-a timely finding given the number of preferred procurement programs emerging across the county. Third, critical evaluation is needed across a diverse set of value chain strategies
\end{abstract}


(e.g., conventional and alternative distribution) if food policy intends to support heterogeneous producers, their communities, and urban food policy goals.

Keywords: food policy; urban-rural linkage; local food; farm; rural development

\section{Introduction}

Urban food policy plans are increasingly popular in cities of all sizes-some smaller than 50,000, others with populations in the millions-all of which are thinking hard about issues around food procurement, urban food production, economic development, food access, the environment, and food recovery [1]. One hundred seventy-nine cities (totaling more than 450 million people) have signed the Milan Urban Food Policy Pact in a commitment to work for more equitable, just, and sustainable urban food systems [2]. Hundreds more, not formally part of any group, are working to engage with community leaders, interest groups, the private sector, and civil society to improve food access and diet quality, minimize waste, and conserve biodiversity. One factor driving metropolitan governments to implement urban food plans is the desire to gain some control over the food system (p. 19 [3]). For example, cities have been working to preserve green space, facilitate community gardens, and invest in shorter food supply chains in recent decades [4].

At the same time, asymmetries between rural (nonmetro) and urban (metro) areas are increasing, with rural areas farther behind in attributes including, but not limited to, health outcomes and medical access [5,6], food availability [7], and broadband connectivity [8]. Specifically, in the United States, the U.S. Department of Agriculture's (USDA) Economic Research Service (ERS) tracks counties that are persistently poor, which it defines as $20 \%$ or more of the population living in poverty, over the last 30 years. Over $85 \%$ of these counties are rural (nonmetro) [9,10]. Further, the rural U.S. lags behind the urban U.S. in recovering from the Great Recession, although it was nearing prerecession unemployment levels as of 2016 [11]. These material inequities are the causes and consequences of growing cultural and social disconnects between rural and urban spaces [12], as evidenced by political cleavages in recent elections in Europe, the U.S., and Brazil, including populist movements such as Brexit $[13,14]$.

There are several ways to tackle rural inequalities and the disconnect with metropolitan residents (e.g., [15-17]). We investigate one possible avenue that has yet to be explored fully in the literature: food systems-driven strategies. Localized food markets tend to be concentrated in urban places given the increasingly urbanized U.S. population, but most farm and ranch products are grown and raised in rural places [18]. At the same time, a growing literature has expressed caution about attempts to satisfy urban food demand by looking only at local (within-the-city) procurement, pointing out links between urban agriculture and gentrification, rising land prices, and population displacement (e.g., [19]). Given the growing global presence and popularity of urban food policy plans, a food systems-led approach has potential to afford opportunities to improve rural livelihoods.

Our research question asks: What opportunities and barriers exist to developing food policies that support urban food goals, specifically related to local procurement, as well as rural economic development? To address this question, we describe and analyze a convening of urban stakeholders-those crafting urban food policies and making purchasing decisions-and larger-scale rural producers. We document and explore 'findings' gleaned from a supply chain diagraming and data compilation process that were then used to guide and inform an event that brought together diverse supply chain partners. These findings are useful to researchers and practitioners looking to leverage the growing popularity of urban food plans to support rural livelihoods and communities.

The following section reviews literature dealing with the building of rural-urban economic linkages, which offer a space to add our understanding of these practices. We then outline our case study: Colorado's Denver Food Vision and Plan [20]. Next, we discuss our methods, a two-step 
process including data compilation of supply chain processes and matrix of factors that affect buyer and producer decision, as well as a meeting with strategic stakeholders. Finally, we present our results, discussion, and opportunities for future research.

\section{Literature Review}

The strengthening of rural-urban linkages is a well-established socioeconomic development strategy (e.g., [21,22]), recognizing that interactions are complex and vary greatly over time and geographical location at both the empirical and conceptual levels [23]. Boundaries along the rural-urban continuum are porous, with continuous economic and social flows [24]. This fluidity has given rise to conceptual and analytical debates about whether talk of the rural (in the singular) is still useful [25]. While the research team acknowledges that the rural-urban binary divide is a "fundamental oversimplification" (p. 128 [26]), by retaining the analytic category, we seek to better understand the different economic features of urban and rural areas and how these spaces are mutually constituting (i.e., rooted and embodied in culture). Further, the authors understand that rural places span a continuum of socioeconomic characteristics, from rural "growth havens" with high amenity levels that are urban-adjacent (as classified by the U.S. Department of Agriculture's rural-urban continuum codes), have natural endowments, and act as commerce hubs, to "lagging rural regions" with geographical remoteness, poor infrastructure, low population density, minimal access to health care, limited employment opportunities, minimal access to broadband, and poor development capacity [27-29]. As such, strengthening rural-urban linkages will not impact rural communities in a homogeneous manner.

Most theoretical research characterizes rural-urban linkages as forms of economic opportunity, particularly for rural areas [30]. These linkages often take the form of the commuting patterns of people and exchange of goods between rural and urban areas that benefit from strengthened market interactions. Both rural residents' ability to migrate to employment opportunities in urban places and to send wages to their home communities and urban consumers' ability to purchase food, feed, fiber, energy, and travel to experience tourism/recreational opportunities from rural areas are thought by many to be a crucial factor in the development of rural areas (e.g., [22,31]).

Empirical research examining the distribution of economic impacts resulting from urban-based economic development initiatives on adjacent rural locales (e.g., the impact of an urban-located vegetable processing plant on adjacent rural vegetable growers) calls into question the ability of urban-based initiatives to support adjacent rural economies. This is because there are more places to spend money in urban places, thus economic flows tend to be stronger from rural to urban than urban to rural (e.g., [32-37]). Although these studies provide clear evidence that industry linkages exist between adjacent rural and urban economies, measured economic flows from urban to rural-adjacent areas are lower than flows in the reverse direction, drawing into question assumptions about the symmetry of the exchanges; the implications for rural development and wealth creation are unclear. While gains may be larger in urban areas, this does not necessarily constitute a simple zero-sum game [18]. Gains in urban areas may not come at the expense of rural regions; instead, there may be benefits in both areas based on comparative advantages and how they can be exploited through increased regional linkages.

\section{Regional Food Systems}

The USDA has promoted local and regional food systems as a core strategy to strengthen rural-urban linkages in the hope of spurring rural community economic development. Local and regional food systems, for example, were one of the USDA's four pillars (the others are production agriculture, the biobased economy, and conservation and natural resources) of agriculture and rural economic development under the Obama Administration [38]. The Rural Development Agency also identified promoting local and regional food systems as one of its seven strategies for economic development [39]. Between 2009 and 2015, the USDA invested over $\$ 1$ billion in more than 40,000 
local and regional food system projects [40]. Most recently, the 2018 Farm Bill created the Local Agriculture Market Program (LAMP) and provides the program with $\$ 50$ million annually in mandatory, permanent funds. LAMP includes a new regional public-private partnership provision that uses federal resources to leverage private investment and encourage "foodshed"-level approaches to developing regional food economies [41].

Local and regional food system initiatives as an economic development strategy focus on strengthening rural-urban linkages through market interactions (e.g., [42-44]). There are increasing opportunity costs associated with urban land in agriculture (given "higher value" uses of the land for other purposes) at the same time that there is increasing interest by urban residents in growing and purchasing local food in cities. Dimitri, Oberholtzer, and Pressman [45] conducted a survey involving 315 urban farms in the U.S. and found that, despite growing interest in urban agriculture, urban farms are relatively small and have limited abilities to produce food. Accordingly, the growing number of urban food policies focused on local procurement inherently involve enhanced linkages with adjacent rural regions, realizing that the capacity to supply some commodities (e.g., milk and eggs) through shortened value chains ("innovative business model[s] in which agricultural producers, manufacturers, buyers, and other related supply chain actors form collaborative, transparent partnerships that attempt to combine product differentiation strategies with commitment to shared operational values and social mission goals" [46]) for some areas is more robust than for other commodities (e.g., fruit and vegetables) [47]. Thus, despite the growing policy interest and support, there is limited research into food initiatives as a rural economic development strategy.

There is reason to believe that local food system strategies may be different than other rural economic development strategies focusing on strengthened rural-urban linkages. Perhaps most importantly, these food system initiatives follow growing consumer demand for locally grown, differentiated products [48]. There is substantial documented evidence that consumers are willing to pay a premium for local food as long as product information is maintained and communicated throughout the supply (or value) chain [44]. While this level of information is relatively easily communicated through direct transactions between farmer and consumer (e.g., farmers markets, farm stands, and community supported agriculture), as demand for local food products has grown, efforts have focused on expanding infrastructure (e.g., food hubs) to scale up localized food sales while maintaining a high level of transparency. Using, locally owned and governed infrastructure is expected to increase the likelihood that the economic value of the input (i.e., farm products) can be maintained and shared with rural producers [49]. This may be different from more typical commodities procured from rural locations and sold in urban markets.

Further, local and regional food system activities are not limited to the financial exchange at the market. Rather, there is growing evidence that the exchange that takes place at the market has broader impacts on both consumers and producers. For example, producers gain ideas for new products from exchanges with customers at markets, and customers gain insight into what is happening on the farm and in rural communities [50]. Consumer willingness to pay a premium for local food, for example, is often due to interest in supporting the ecological, social, cultural, and economic sustainability of farms $[44,51,52]$. The dissemination of information associated with these credence attributes often comes in the exchange of information from rural farm owner to consumer. Accordingly, there is at least preliminary evidence that local and regional food system activities can support positive outcomes through strengthening rural-urban linkages [53]. However, despite this preliminary evidence, we were not able to identify any literature that looks at the role of farmers, and particularly those of scale, in urban food planning processes.

\section{Background: Denver Food Vision and Plan}

In 2015, and in line with the efforts of other cities, counties, municipalities, and regions across North America (e.g., [54,55]), the City and County of Denver began developing its first long-term strategic vision for the future of food in the city and county. The Denver City Council and the Mayor's 
Office supported the development of a comprehensive, citywide food plan to bring about greater alignment across the wide range of stakeholders with a clearer understanding of the role of government in food systems planning and development [20]. The resulting document, the Denver Food Vision and Plan, emerged from a public engagement process that generated a total of 4918 comments from 22 listening sessions and focus groups. The Vision includes four key focus areas (pillars): inclusive, healthy, vibrant, and resilient [20]. To support greater alignment and evaluation of collective impact, the Vision also includes measurable "winnable goals" in each focus area, as well as a series of supporting indicators to track progress from baseline through the year 2030 (see Table 1). In the Vision, "winnable goals" are defined as "tangible, measurable impacts that demonstrate achievement of the priorities" (p. 7 [20]). Here, we are concerned with the focus area of creating an economically vibrant food system, which explicitly involves strengthening the market-based linkages between rural and urban areas. For example, one of the winnable goals is that $25 \%$ of all food purchased by public institutions in the City and County of Denver come from Colorado.

Table 1. Denver Food Vision Pillars.

\begin{tabular}{|c|c|c|}
\hline $\begin{array}{l}\text { Denver Food } \\
\text { Vision Pillar }\end{array}$ & Priority & Winnable Goals ${ }^{1}$ \\
\hline \multirow{2}{*}{ Inclusive } & $\begin{array}{l}\text { Invest in community-driven complete } \\
\text { neighborhood food environments }\end{array}$ & \multirow{2}{*}{$\begin{array}{l}\text { Five low-income or underserved neighborhoods reach self-defined } \\
\text { goals for a complete food environment } \\
7 \% \text { increase in number of community school gardens } \\
15 \% \text { increase in residential sales and food-producing permits }\end{array}$} \\
\hline & $\begin{array}{l}\text { Expand community food production } \\
\text { and sharing }\end{array}$ & \\
\hline \multirow{4}{*}{ Healthy } & $\begin{array}{l}\text { Improve access to a wide variety of } \\
\text { healthy food retail options }\end{array}$ & \multirow{4}{*}{$\begin{array}{l}\text { Reduce percentage of food insecure households by } 45 \% \\
\text { (from } 18 \% \text { to } 8 \% \text { ) } \\
\text { Increase enrollment in SNAP for eligible populations by } 52 \% \\
\text { (from } 59 \% \text { eligible enrolled to } 80 \% \text { ) } \\
\text { Increase adult and child fruit and vegetable consumption by } 14 \% \\
\text { (from } 2.8 \text { servings per day to } 3.2 \text { per day) } \\
\text { Reduce the number of children drinking sugary drinks daily by } 35 \% \\
\text { (from } 26 \% \text { to } 17 \% \text { ) }\end{array}$} \\
\hline & $\begin{array}{l}\text { Ensure that healthy food is affordable } \\
\text { for everyone }\end{array}$ & \\
\hline & $\begin{array}{l}\text { Promote healthy food environments } \\
\text { and education for youth }\end{array}$ & \\
\hline & Increase demand for healthy foods & \\
\hline \multirow{3}{*}{ Vibrant } & $\begin{array}{l}\text { Promote Denver as an epicenter for } \\
\text { regional food economy }\end{array}$ & \multirow{3}{*}{$\begin{array}{l}\text { Increase size of the Denver food economy by } \$ 500 \mathrm{M} \\
\text { (from } \$ 6.9-7.4 \text { B per year) } \\
\text { Attract } \$ 100 \mathrm{M} \text { of new capital to Denver food businesses } \\
\text { - } 25 \% \text { of all food purchased by public institutions comes from Colorado }\end{array}$} \\
\hline & $\begin{array}{l}\text { Support the creation, expansion, and } \\
\text { success of food businesses in Denver }\end{array}$ & \\
\hline & $\begin{array}{l}\text { Spur innovation and entrepreneurship } \\
\text { across food and agricultural industries }\end{array}$ & \\
\hline \multirow{2}{*}{ Resilient } & $\begin{array}{l}\text { Preserve remaining regional food } \\
\text { system assets and infrastructure }\end{array}$ & \multirow{2}{*}{$\begin{array}{l}\text { Preserve and maintain } 100 \text { acres of prime regional agricultural working } \\
\text { lands in active production } \\
\text { - } 34 \% \text { reduction in residential food waste collected through municipal } \\
\text { solid waste services (from } 20,000 \text { tons in } 2008 \text { ) }\end{array}$} \\
\hline & $\begin{array}{l}\text { Promote environmentally responsible } \\
\text { and climate-smart food systems }\end{array}$ & \\
\hline
\end{tabular}

${ }^{1}$ In the Denver Food Vision, "winnable goals" are defined as "tangible, measurable impacts that demonstrate achievement of the priorities" (p. 7 [20]).

\section{Methods}

To investigate how the proposed market opportunities resulting from the Denver Food Vision and Plan might support rural Colorado farmers, we used a two-step process-a framing of supply chain processes and a meeting with strategic stakeholders. To support visualization of the supply chain, we assembled data on existing supply chain linkages, including prices and quantities of commodities sold, methods of transportation, processors, distributors, and end consumers. Where needed, we also conducted primary interviews with both farmers and supply chain businesses. In addition, we compiled information on a matrix of factors that could affect (positively or negatively) buyer or producer decisions to purchase or supply product. The supply chain linkages research and matrix of factors helped guide the conversation in the second step of our research-a meeting between producers and urban policymakers aimed at identifying opportunities and barriers associated with local, urban procurement from larger-farmers. The supply chain linkages diagrams and matrix of decision factors were used to focus and ground the meeting, providing data and evidence regarding the nature of supply chains and their dynamics. The meeting included urban policymakers and buyers, 
larger-scale potato, peach, and sweet corn producers, and support organizations (e.g., extension agents, economic developers, and Colorado State University researchers). Further, urban stakeholders provided information on policy tools and expanded market opportunities resulting from the Denver Food Vision and Plan. In this section, we describe methods employed to both generate data on supply chain linkages and the matrix of buyer and producer decisions, and to guide the planning and analysis of the stakeholder meeting.

\subsection{Data on Supply Chain Linkages and Matrix of Buyer and Producer Decision Factors}

Supply chain diagrams serve as visual models of the key inputs, outputs, and social agents involved in growing, processing, distributing, marketing, and selling agricultural products. In addition to traditional metrics of price and volume, this research aimed to understand broader rural development outcomes associated with potential welfare changes for producers, supply chain agents, and consumers. Supply chain diagrams helped us track the people and firms who interact with an agricultural good at various stages of production, distribution, and consumption, thereby allowing us to better identify and understand the implications of a policy change within a complex food system (e.g., $[56,57])$.

To support the meeting and facilitate conversations between urban buyers and policymakers and potato, sweet corn, and peach growers, we produced supply chain diagrams for potatoes and peaches (though sweet corn growers were included in the meeting, the focus was on the other two represented commodities). Potato, sweet corn and peach growers were selected as potatoes are the most economically important specialty crop grown in the state (representing one-half of all fruit and vegetable sales), and sweet corn and peaches are perceived by Coloradoans to be the top products grown or raised in the state [58].

As a first step, we gathered data from available secondary sources, including production and processing information from the U.S. Department of Agriculture's National Agricultural Statistics Service, Economic Research Service, and Agricultural Research Service [59-64]. We also consulted industry reports published by extension services and commodity groups to gain insight into how supply chains differed among crops [65-68]. For the peach supply chain, given the common usage of direct markets, we incorporated Colorado-specific farmers' market and direct marketing information $[69,70]$.

For the potato supply chain, given that Colorado potatoes are subject to a marketing order, the Colorado Potato Administrative Committee made significant data available. Unfortunately, that level of supply chain data was not available for peaches. Accordingly, to gain greater insight into the more fragmented peach supply chains, a Colorado State University graduate student spent eight weeks on the Western Slope of Colorado during the summer of 2018 interviewing peach producers. In total, the student interviewed 14 producers (and 8 other "support" stakeholders). The semi-structured interviews were comprised of 18 questions, 10 of which were open-ended. The questions focused on production practices, supply chain linkages, current markets, and perceptions of future market opportunities. We analyzed data from the interviews to determine patterns in producer size, picking and packing processes, and supply chain paths for peaches grown in the Western Slope region of Colorado. We distilled this information into an overview supply chain that breaks down the movement of peaches from field to consumer and represents the many packing and distribution options available to a typical rural Colorado peach producer. Most individual producers take advantage of only a single packing option, but we identified up to three distribution options that producers use. Once we had developed an overview supply chain containing all distribution paths mentioned in interviews, we generated individual supply chains for each producer studied to get a sense of the most common packing and distribution mechanisms in the state of Colorado.

In addition, to complement the supply chain diagrams and provide more useful information for producers considering diversifying markets, a matrix of factors that represent important aspects of buyer and producer decisions was developed based on past research [48,71-75] and discussions 
with producers about their decision-making criteria. The matrix illustrates how the various product differentiation mechanisms that buyers may prefer and that producers may then choose to offer will influence a broader set of food system issues.

\subsection{Gunnison Meeting: Process and Observation}

The methods for the meeting had two primary components, that of process and that of observation. The process piece included planning the event, determining who was included, what their role would be, and how to shape the agenda. The observation piece included participant observation methods and analysis. Both are described in this section.

We intentionally limited producer attendance to larger-scale (based on acreage and/or revenue) and more established growers (all but one were from multigenerational farms). We did this for three primary reasons:

- First, in the experience of the event organizers (extension specialists, agents and researchers who collectively have decades of experience working with farmers in Colorado), small- and mid-scale growers (particularly those interested in scaling up) watch what larger, more established producers do in response to new marketing opportunities. Individuals throughout rural places notice a shift in market strategy by a larger grower much more broadly than changes by small- and mid-scale producers.

- Second, larger producers are generally more able and willing to take risks with new market opportunities given their enhanced ability to absorb losses and access the capital necessary to take advantage of them.

- Third, larger producers can supply products at lower prices and larger quantities relative to smaller-scale producers. Given that many of the urban market opportunities are focused on institutional procurement (e.g., jails and schools), we anticipated that the budget for procurement may be too rigid to accommodate the premium price requirements of small-scale producers.

We invited the Denver-based policymakers and buyers based on their potential to develop market opportunities that would directly align with changes to Denver's food policies. For example, three attendees represented public markets that were in the process of developing, one individual represented a company creating market opportunities for products that would otherwise be wasted, and another was involved with procurement for the City and County of Denver. Additionally, we selected the meeting's location to signal that urban policymakers, buyers, and support organizations were committed to addressing barriers associated with connecting rural and urban areas, as many attendees had to travel 200 miles southwest from Denver. Moreover, Gunnison, Colorado, is a midway point among the major peach, sweet corn, and potato growing regions in the state. In this way, urban policymakers were recruited based upon expressed and actual interest for encouraging regional food system economies.

The agenda and facilitation of the two-day meeting sought to build trust among participants such that their opinions and thoughts would be genuinely heard. For example, a trained facilitator led the meeting and a pre-meeting social event at a brewery was organized for the group. The research team also secured funding to cover all travel, lodging, and meal costs to lower barriers to participation.

The meeting agenda aimed to identify "commonalities" across the various groups present. The goals of the day were outlined in a presentation that included: (1) How can Denver's food policies create new and/or higher value market opportunities for producers and regional supply chain businesses? (2) Are additional investments needed? (3) How can producers and regional leaders be more fully integrated in policymaking processes and programming priorities? We organized the agenda around speakers representing Denver policymakers and buyers in the morning, followed by producer feedback, explanations of the supply chains and matrix of factors described above, breakout sessions, and synthesis/next steps. 
For the participant observation, Colorado State University staff took careful notes on the setting, unfolding of the agenda, what participants said, how they interacted, where they sat, and perceived levels of engagement during different presentations. The aim was to generate a thick description beginning with grand-tour questions about the general place, topics, gestures, and interactions followed by mini-tour questions focusing on specifics of individuals and interactions and our feelings and perceptions as researchers [76]. These detailed notes were then compared with other research team member's notes. Over the course of a series of meetings and exchanges among the lead authors, key themes were identified.

\section{Results}

\subsection{Supply Chain Linkages Diagram and Matrix of Buyer and Producer Decision Factors}

This research examined some of the key factors in connecting urban food system stakeholders and rural producers as it relates to how Denver's food policy work can improve both urban and rural economies. Figure 1 shows an example of a visual representation of a potato supply chain that we used to depict how some of Denver's new buying priorities may change current marketing relationships (see shaded boxes). Of note, and as we communicated in the workshop, is that the primary and secondary data do not suggest changes at the input, seed, or organizational level. Rather, industry players would start to consider a wider portfolio of choices starting at the shipping points, transportation, value-added businesses, and food manufacturers. Here, value-added can be thought of as any sort of differentiation from the commodity market (e.g., bagging potatoes in smaller packaging, using farm identifiers in marketing, and organic certification). Manufacturing here refers to more significant product form changes (e.g., chips, mashed, and potato salad). However, it is likely that too few data are available to support changes to the grey boxes alone in supporting the type of informed decisions that have historically been made on commodity markets.

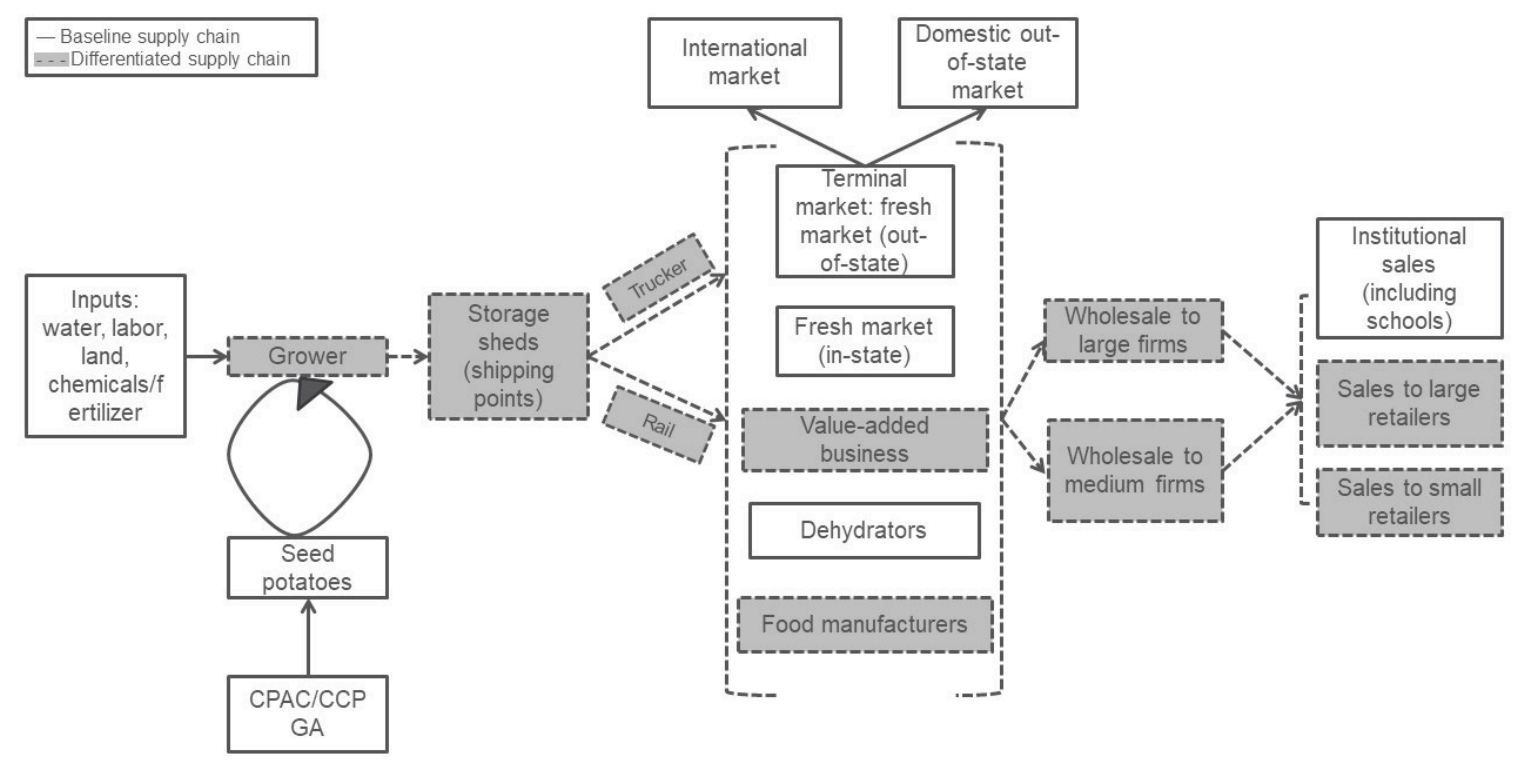

Figure 1. Potato supply chain, including differentiated supply chain. CPAC, the Colorado Potato Administrative Committee; CCPGA, the Colorado Certified Potato Growers Association.

To provide additional information to inform the meeting, we created a matrix of factors to help explore important aspects of buyer and producer decisions in more localized procurement (Figure 2). The differentiation strategy framed is in the center of the matrix, including colored-flesh potatoes, value-added products and dehydrated processing. On the left of this center column, several potential producer impacts are listed, reflecting expected differences in costs, skilled human capital and risk. For the producer-focused factors, the upward and downward orientation of the arrows and equal 
sign represent the hypothesis of whether we expect the product differentiation strategy to increase, decrease or have little influence $(=)$ on that aspect of the producer's operations. On the right side of the matrix, we incorporated potential benefits to consumers and communities resulting from the Good Food Purchasing Program (a metrics based standard that the City and County of Denver, like many other cities across the U.S., are considering adopting to measure and assess their procurement standards, see: https:/ / goodfoodpurchasing.org/program-overview/.) For these buyer-side aspects, the plus, minus or equal sign represent the hypothesis of the potential benefits, costs or minimal effect $(=)$ of that differentiation on a key goal of the Good Food Purchasing Program.

\begin{tabular}{|c|c|c|c|c|c|c|c|c|c|c|}
\hline $\begin{array}{l}\text { Financial } \\
\text { Outlays }\end{array}$ & $\begin{array}{l}\text { Transaction } \\
\text { Costs }\end{array}$ & $\begin{array}{l}\text { Records/ } \\
\text { Business } \\
\text { Process }\end{array}$ & $\begin{array}{l}\text { Risk (Yield } \\
\text { or Price) }\end{array}$ & $\begin{array}{l}\text { Mgmt. } \\
\text { Effort/ } \\
\text { Expertise }\end{array}$ & $\begin{array}{l}\text { Strategy or } \\
\text { Mechanism }\end{array}$ & $\begin{array}{c}\text { Local } \\
\text { Economies }\end{array}$ & $\begin{array}{l}\text { Environmental } \\
\text { Sustainability }\end{array}$ & $\begin{array}{l}\text { Valued } \\
\text { Workforce }\end{array}$ & $\begin{array}{l}\text { Animal } \\
\text { Welfare }\end{array}$ & Nutrition \\
\hline$\uparrow$ & 个 & 1 & $\mathbf{A}$ & $\boldsymbol{N}$ & $\begin{array}{l}\text { Value-added } \\
\text { products } \\
\text { (healthy snack) }\end{array}$ & + & - & + & $=$ & $+/-$ \\
\hline 1 & $\boldsymbol{A}$ & $=$ & $\downarrow$ & $=$ & $\begin{array}{l}\text { Increased } \\
\text { volume to } \\
\text { dehydration }\end{array}$ & + & + & + & $=$ & $=$ \\
\hline$=$ & 1 & $=$ & 1 & $\boldsymbol{1}$ & $\begin{array}{l}\text { Colorful } \\
\text { varieties }\end{array}$ & + & $=$ & $=$ & $=$ & + \\
\hline
\end{tabular}

Figure 2. Matrix of factors to explore buyer and seller implications of potato supply chain differentiation. Baseline product: Five-pound bag of russet potatoes marketed through national retailer. For the left-hand side, the upward and downward orientation of the arrows and equal sign represent the hypothesis of whether we expect the product differentiation strategy to increase, decrease or have little influence $(=)$ on that aspect of the producer's operations. For the right-hand side, the plus, minus or equal sign represent the hypothesis of the potential benefits, costs or minimal effect $(=)$ of that differentiation on a key goal of the targeted good food purchasing program.

For example, Colorado State University potato breeding programs have invested in developing potato lines with more diverse flesh colors (purple, yellow, red) in response to evidence that there may be nutritional benefits from the consumption of such potatoes, but that potential benefit would need to be researched to see if it is worth enough premia to buyers that they could offer Colorado producers enough to offset the additional costs, skill or risk they would face.

\subsection{Results from Gunnison Meeting Process and Observation: Opportunities and Tensions}

The meeting occurred on a cold day with blue skies in the South Ballroom in the student center of Western Colorado State University in Gunnison, Colorado. The meeting room had high ceilings, no windows, and was approximately $70^{\prime} \times 70^{\prime}$. There were six round tables for attendees, each complete with pencils, CSU folders with agendas, name cards, and a condensed copy of the Colorado Blueprint of Food and Agriculture [58] for each participant. There was a stage at the center front of the room set with a table for the panelists, and a large screen for PowerPoint presentations. The thirty-nine people were scattered throughout the available tables such that tables generally had a mix of producers, researchers, policymakers, and buyers.

Throughout the Gunnison event, discussions surrounding potential Denver policies brought up some key areas of tension and opportunity. Herein, we group these issues into three broad topic areas:

- the urban framing of food policy as an opportunity to address food access/security issues;

- the influence and necessity of integrating supply chain stakeholders; and

- the tensions and tradeoffs in defining "good food", including issues of scale bias and third-party verification. 


\subsubsection{The Urban Framing of Food Policy as an Opportunity to Address Food Access/Security Issues}

Denver policymakers and guiding documents often frame food system development in terms of food access, security, and affordability issues. This is largely because public health challenges often motivate urban stakeholders to participate in food-planning processes. For example, Denver stakeholders who participated in the Food Vision voted for "Healthy Denver" as the most important pillar included in the Vision and Plan (receiving 38\% of total votes), compared to the "Vibrant Denver" pillar (receiving 11\%), which is focused on economic development [20].

Although the food access and food security issues brought up by Denver participants in Gunnison were married to the potential to create market opportunities for rural producers (e.g., additional local procurement in institutions and corner stores), this framing appeared to create a disconnect between rural and urban stakeholders. As evidence, researchers at the meeting tracked participant engagement with speakers through participant observation. As participants deliberated during discussions about food access and security in Denver, fewer participants were looking at the presentations and were more likely to be leaning over, looking down at their smartphones, getting up to stand, or leaving the room. Further, several producers commented that they perceived that food access and security policies in Denver had little to do with them. Even though the invited producers are very politically engaged, traveling frequently to Washington, D.C. to meet with Federal policymakers, very few of them raised their hands when asked about familiarity with Denver's Food Vision or other health food initiative policy proposals. One producer noted, “If you look around, no one raised hands because we didn't know about such policies. We need more connection if we are to work together".

Thus, while Denver's growing interest in food is largely driven by a desire to improve the food access and food security of its residents, policymakers and buyers are working to leverage this buying power to support the state's rural agricultural economy so that it can have a larger potential impact. Moving forward, policymakers and buyers need to be more cognizant of the language that they use if a goal is to develop and deepen marketing connections with producers. At the same time, in order to leverage emerging market opportunities in U.S. cities, including Denver, growers will need to become more attuned to urban food policies and planning processes.

\subsubsection{The Influence and Necessity of Integrating Supply Chain Stakeholders}

After the supply chain diagrams were shown, and conversations ensued regarding the matrix of factors, many producers commented on the absence of supply chain stakeholders at the convening. Producers explained their concerns about managing transaction costs and the management efforts/expertise necessary to shift from a traditional supply chain to a value chain. In particular, they saw a need for participation from key logistical experts to assist with the transport of products from rural areas to supply Denver markets. Several times during the meeting, producers asked why distributors such as Sysco and Sodexo were not in the room. Producers mentioned the pivotal role that these supply chain actors play in aggregating and transporting products and in supplying larger-scale markets.

At the same time, Denver stakeholders discussed the need to develop alternative food value chains with reduced reliance on the large food distribution companies. Several policymakers and buyers mentioned the need to create a food hub or other "new" infrastructure to support regionalized procurement, alluding to concerns that traditional middlemen (e.g., Sysco) may not assure better or more stable returns to producers. However, several producers see mainstream distributors as helpful and unbiased in developing regional food systems. As one person said, "Sysco doesn't care about what it's taking from one place to another. If policy is made to support local, Sysco and the market will adapt." However, a CSU researcher pointed out that large distributors are for-profit and often end up not equitably distributing value or premiums back to supplying producers.

A moment of understanding during the meeting came when a CSU researcher talked about the need for different models to coexist. The researcher framed and named these as the "interstate" and "scenic byways" models. The "interstate" model involves distribution by such middlemen as Sysco and 
Sodexo to supply institutions all over the country, with the primary focus being on efficient movement of large volumes and diverse offerings of products. By contrast, the "scenic byways" model describes a marketing route for growers who aim to create added value through product differentiation and retaining their farms' identities as sources of produce, all which may be more credibly managed through a locally governed food value chain model or approach. A grower described the challenge of working with institutional buyers, saying that the "buyers" world is getting bigger and buyers like working with big vendors. Thus, the "scenic byway" model creates an alternative for those who want to compete and gain value by cutting out middleman distributors. Producers joked that the "scenic byway" model favors those who are willing to "pet peaches" and sell them to consumers who can afford to care about particular farm business practices that may have significant cost implications. Although overly simplistic, this example broke any potential tension in the room around different production models, given that several producers noted their lack of interest in being quite so consumer responsive. Based on these discussions, there is an opportunity to integrate distributors and aggregators more fully into the conversation and identify strategies to supply Colorado-grown product at affordable prices, while ensuring that some premia make their way to the producer. The conversation reinforced opportunities and distribution models that support different scales, business models, and diverse markets.

\subsubsection{The Tensions and Tradeoffs in Defining "Good Food", Including Issues of Scale Bias and} Third-Party Verification

An underlying tension throughout the event was that the Denver food policies inherently imposed a value judgement about what "good food" is, including how it is grown, who grows it, and how it is distributed. Although well-intentioned, Denver's working definitions of "good" often contrasted with what producers saw as the realities of farming.

As with many cities across the U.S., Denver is considering participating in the Good Food Purchasing Program, which provides a comprehensive set of tools, technical support, and verification system to assist institutions in meeting their procurement goals [77]. Accordingly, Denver's Food Systems Administrator briefly presented on the areas covered by the program (i.e., environmental sustainability, valued workforce, animal welfare, and nutrition) as well as the types of third-party verification and metrics involved. Farmers noted that some aspects of the program did not adequately account for the context within which producers make choices about production practices.

For example, the Good Food Purchasing Program rewards procurement from midscale producers. However, given the framing of food programs and initiatives to address issues of food security and access, producers noted that it can be challenging to execute such supply chains profitably. As one fruit grower said, "regenerative and organic produce is a higher price because it is tougher to produce. This makes the affordability tough for low-income populations". Growers also noted that Colorado produces significantly larger quantities of potatoes, sweet corn, and peaches than Denver could use. They expressed concern over alienating their other regional and national markets through "buy local" programs.

Overall, farmers expressed disappointment at their perception of the lack of openness and transparent communication as the urban food policies were being framed and discussed. As one person stated, "people don't understand potatoes. People say we shouldn't eat too many or question [the] sustainability [of our growing practices] or how employees are treated. I get upset when I hear some of this. Farmers care about their families and feed communities ... Consumers should not dictate what farmers do." Producers would like to be more involved in the creation and adoption of standards, such as those outlined in the Good Food Purchasing Program, especially because such standards run the risk of obfuscating the heterogeneity of rural growing conditions, infrastructure, communities, water availability, and people. At the same time, the fact that urban policymakers and buyers traveled to and participated in the meeting shows interest in deepening relationships and communications with statewide producers. 


\section{Discussion and Future Research}

Three findings from our supply chain diagramming, matrix of factors to factors to explore important aspects of buyer and producer decisions and Gunnison discussion process and observation stand out:

- facilitating dialog between urban food policymakers and rural producers to understand potential tensions, mitigate such tensions, and capitalize on opportunities is essential;

- perceptions and expectations surrounding "good food" are nuanced-a timely finding given the number of preferred procurement programs emerging across the county; and

- critical evaluation is needed across a diverse set of value chain strategies (e.g., conventional and alternative distribution) if food policy intends to support heterogenous producers, their communities, and urban food policy goals.

The Denver Food Vision case study presents a unique opportunity to investigate "the extent to which influences between rural and urban areas are symmetrical rather than asymmetrical, as is typically portrayed, i.e., on bidirectional relational aspects of spatial categories" (p. 567 [24]). Perhaps of greater interest is how the influences vary from one direction to the other, and how different strategies may alter the bidirectional flows. For example, increased demand for regionally or locally sourced food is reflective of a general shift in rural economies that is increasingly driven by consumption trends-consumption that is largely associated with and driven by urban areas [78,79]. However, several discussion points at the Gunnison meeting, guided in part through the supply chain diagram and matrix of factors, indicate a disconnect between urban buyers' perceptions of what would support rural areas and the rural producers' thoughts on how their enterprises would be impacted by changes in product characteristics and marketing strategies.

Our observations reiterate the need to create still further opportunities for food system stakeholders to engage each other. Clear differences in language that emerged at the Gunnison meeting between urban and rural stakeholders mask potential opportunities and inhibit direct communication. This finding focused on challenges with language and communication is certainly in line with previous literature (e.g., [80,81]), but perhaps this effort was unique in its attempt to meaningfully engage larger-scale producers with urban buyers and policymakers. For example, to engage in collaborative food system opportunities, Kloppenburg et al. [81] engaged a group from the "alterative farming community". Although these efforts are laudable, they still create a "binary" [82] that arguably does not serve to support the breadth of opportunities (or address challenges) throughout the food system.

Even though many cities, including Denver, frame their interest in food systems planning primarily around food access and food security issues when it comes to broader public health issues [1], perhaps these goals could be used to support new market opportunities for rural producers if they included their voices and input. To do this, producers, including those of scale, need to be engaged early and often. Perhaps there is no possibility to fully align buyers' intentions with the reality of producers' management constraints, but at the margin, doing so will increase the likelihood of the formation of viable new marketing arrangements. In reality, the traditional institutional procurement route is better positioned to work with larger-scale producers who can help achieve affordability goals; other "good food" goals may unintentionally require producers to charge higher prices to remain viable.

Through the data presented at the Gunnison meeting, as well as the conversations that took place, it is evident that there is not one but many solutions for building connectivity between rural communities, producers, urban policymakers, and buyers. Some farmers could clearly benefit by working with existing distribution systems and firms. However, that option is neither attractive nor viable for all producers. Some literature shows that traditional supply chains usually push additional costs onto farmers, and these expenses are often cost prohibitive except among the largest growers [83]. Moreover, urban local and regional procurement strategies may not support that the value generated by so-called middlemen remains with rural communities. Alternative, parallel distribution systems 
directed at the needs and interests of midscale producers, which also employ rural residents and support rural economies [84], were an important missing element identified by a number of growers if these linkages are to improve rural livelihoods. However, these alternative distribution systems have their own challenges, and can struggle to operate profitably (e.g., [85]). Thus, continued conversations can help to define multiple strategies that meet heterogenous urban and rural stakeholder needs.

It also became clear that the multiple meanings of "good food" are nuanced and rooted to identifiers sometimes associated with competing understandings of the public good, aspects of food systems, and what it means to be a "good" and financially sustainable farmer (e.g., [86-88]). It is important for these underlying assumptions and their implications to be discussed and explored before policies are set. Doing this early in the process also helps build trust and empathy among stakeholders, which helps facilitate further group dialog and cohesion. In short, thoughtfully structured workshops, using data-driven approaches, and that garner critical feedback rather than just compliance with initially stated goals are critical to moving rural-urban discussions forward.

\section{Limitations and Future Research}

As with all research, this study has several limitations. First, it likely would have been useful to include a pre-post survey to gather more rigorous input on the extent to which meeting participants thought they could adequately or fully participate, the types of questions and concerns driving dialog, whether key stakeholders were missing from conversation, and the utility of the supply chain diagram and matrix of factors.

Second, through an inclusive, deliberative lens, one limitation could be that this research focused on larger-scale producers, rather than other actors in the value chain, levels of governance, and alternative socio-cultural networks. However, we attempted to justify in-text our rationale for selecting these producers as a starting point, and are cautiously optimistic that integrating this particular group of stakeholders into urban food planning will have broader implications for the agricultural community. Further, there are already indicators that this choice was successful (for example, the Colorado Potato Administrative Committee submitted a Specialty Crop Block Grant application to the Colorado Department of Agriculture to work with Denver Public Schools following the Gunnison event), and future efforts will aim for more work across heterogeneous actors.

Finally, the research team is aware that the process of outreach and deliberation must be iterative, building upon what worked and what did not work. Accordingly, we have several future events and meetings planned to continue conversations. Perhaps most notably, following the Gunnison meeting the City and County of Denver have opened a door for a producer subcommittee to weigh in on procurement decisions.

Author Contributions: Conceptualization, B.B.R.J, M.C., D.T.M. Data curation, B.B.R.J., M.C., J.H., D.T.M., E.L., T.C., O.D., A.S.J., M.S., M.U. Formal analysis, B.B.R.J., M.C., J.H., D.T.M., E.L., T.C. Funding acquisition, B.B.R.J., M.C., D.T.M., L.B., R.C., O.D., A.S.J., P.M., J.Q., E.P.R., M.S., M.U. Methodology, B.B.R.J., M.C., J.H., D.T.M., L.C., L.B., R.C., M.C. Writing original draft, B.B.R.J., M.C., J.H., D.T.M., E.L., L.C., T.C., L.B., R.C., O.D., K.E.J., A.S.J,, P.M., J.Q., E.P.R., M.S., H.S., M.U. Writing review and editing. B.B.R.J., M.C., J.H., D.T.M., E.L., K.E.J.

Funding: The research reported in this publication was supported by Colorado State University's Office of the Vice President for Research Catalyst for Innovative Partnerships Program, the Foundation for Food and Agriculture Research, the Colorado Potato Administrative Committee, and the Colorado Agricultural Experiment Station.

Acknowledgments: We would like to thank the farmers, policy makers, buyers, extension agents and others who participated in this convening and continue to be working to support food systems led economic development.

Conflicts of Interest: The authors declare no conflict of interest. The content is solely the responsibility of the authors and does not necessarily represent the official views of the funding organizations. 


\section{References}

1. Johns Hopkins Bloomberg School of Public Health. Directory of Food Policy Networks. Available online: http:/ / www.foodpolicynetworks.org/directory / (accessed on 1 March 2019).

2. Milan Urban Food Policy Pact. More than 100 Cities Signed the Milan Urban Food Policy Pact Presented to UN Secretary General. Available online: http:/ / www.milanurbanfoodpolicypact.org/2015/10/15/morethan-100-cities-signed-the-milan-urban-food-policy-pact-presented-to-un-secretary-general/ (accessed on 1 March 2019).

3. Bricas, N. What are the stakes for city food systems? In Proceedings of the Urban Food Policies: International Meeting on Experiences in Africa, Latin America and Asia, Montpellier, France, 16-18 November 2015; pp. 15-200.

4. Cockrall-King, J. Food and the City: Urban Agriculture and the New Food Revolution; Prometheus Books: Amherst, NY, USA, 2012; ISBN 978-1-61-614458-6.

5. Fontanella, C.; Hiance-Steelesmith, D.; Phillips, G.; Bridge, J.; Lester, N.; Sweeney, H.; Campo, J. Widening rural-urban disparities in youth suicides, United States, 1996-2010. JAMA Pediatr. 2015, 169, 466-473. [CrossRef]

6. Hall, K.S.; Dalton, V.; Johnson, T.R.B. Social disparities in women's health service use in the United States: A population-based analysis. Ann. Epidemiol. 2014, 24, 135-143. [CrossRef]

7. Walker, R.E.; Keane, C.R.; Burke, J.G. Disparities and access to healthy food in the United States: A review of food deserts literature. Health Place 2010, 16, 876-884. [CrossRef]

8. Aguliar, J. Colorado Divide: Broadband Gaps Threaten to Leave Rural Areas in the Dust of Digital Age. The Denver Post, 8 September 2017.

9. U.S. Department of Agriculture, Economic Research Service (USDA ERS). Geography of Poverty. 2017a. Available online: https:/ / www.ers.usda.gov/topics/rural-economy-population/rural-poverty-well-being/ geography-of-poverty.aspx (accessed on 1 March 2019).

10. U.S. Department of Agriculture, Economic Research Service (USDA ERS). Poverty Overview. 2017b. Available online: https:/ / www.ers.usda.gov/topics/rural-economy-population/rural-poverty-well-being/ poverty-overview / (accessed on 1 March 2019).

11. Kusmin, L. Rural America at a Glance; U.S. Department of Agriculture, Economic Research Service: Washington, DC, USA, 2016.

12. Carolan, M. Justice across real and imagined food worlds: Rural corn growers, urban agriculture activists, and the political ontologies they live by. Rural Sociol. 2018, 83, 823-856. [CrossRef]

13. Jensen, J.B.; Quinn, D.P.; Weymouth, S. Winners and losers in international trade: The effects on US presidential voting. Int. Organ. 2017, 71, 423-457. [CrossRef]

14. Colantone, I.; Stanig, P. Global competition and Brexit. Am. Polit. Sci. Rev. 2018, 112, 201-218. [CrossRef]

15. Cei, L.; Defrancesco, E.; Stefani, G. From geographical indications to rural development: A review of the economic effects of European Union policy. Sustainability 2018, 10, 3745. [CrossRef]

16. Riva, F.; Ahlborg, H.; Hartvigsson, E.; Pachauri, S.; Colombo, E. Electricity access and rural development: Review of complex socio-economic dynamics and causal diagrams for more appropriate energy modelling. Energy Sustain. Dev. 2018, 43, 203-223. [CrossRef]

17. Salemink, K.; Strijker, D.; Bosworth, G. Rural development in the digital age: A systematic literature review on unequal ICT availability, adoption, and use in rural areas. J. Rural Stud. 2017, 54, 360-371. [CrossRef]

18. Jablonski, B.B.R.; Hendrickson, M.; Vogel, S.; Schmit, T. Local and Regional Food Systems Driving Rural Economic Development: Investing in, Expanding, and Supporting Local and Regional Food Systems; U.S. Department of Agriculture and Federal Reserve System: Washington, DC, USA, 2017.

19. Horst, M.; McClintock, N.; Hoey, L. The intersection of planning, urban agriculture, and food justice: A review of the literature. J. Am. Plan. Assoc. 2017, 83, 277-295. [CrossRef]

20. Denver Office of Economic Development (DOED). Denver Food Vision: Draft for Public Review and Comments. 2016. Available online: https:/ /www.denvergov.org/content/dam/denvergov/Portals/690/ Healthy\%20Food/FoodVision-draft122116.pdf (accessed on 1 March 2019).

21. Irwin, E.G.; Isserman, A.M.; Kilkenny, M.; Partridge, M.D. A century of research on rural development and regional issues. Am. J. Agric. Econ. 2010, 92, 522-553. [CrossRef]

22. Tacoli, C. Rural-urban interactions: A guide to the literature. Environ. Urban. 1998, 10, 147-166. [CrossRef] 
23. Adam, C.; Bevan, D.; Gollin, D. Rural-urban linkages, public investment and transport costs: The case of Tanzania. World Dev. 2018, 109, 497-510. [CrossRef]

24. Lichter, D.T.; Brown, D.L. Rural America in an urban society: Changing spatial and social boundaries. Ann. Rev. Sociol. 2011, 37, 565-592. [CrossRef]

25. Bell, M.M. The two-ness of rural life and the ends of rural scholarship. J. Rural Stud. 2007, 23, 402-415. [CrossRef]

26. Partridge, M.; Bollman, R.D.; Olfert, M.R.; Alasia, A. Riding the wave of urban growth in the countryside: Spread, backwash, or stagnation? Land Econ. 2007, 83, 128-152. [CrossRef]

27. Drabenstott, M. New policies for a new rural America. Int. Reg. Sci. Rev. 2001, 24, 3-15. [CrossRef]

28. Ilbery, B.; Maye, D.; Kneafsey, M.; Jenkins, T.; Walkley, C. Forecasting food supply chain developments in lagging rural regions: Evidence from the UK. J. Rural Stud. 2004, 20, 331-344. [CrossRef]

29. Wu, J.; Gopinath, M. What causes spatial variations in economic development in the United States? Am. J. Agric. Econ. 2008, 90, 392-408. [CrossRef]

30. Porter, M.; Miller, K.; Bryden, R. Competitiveness in Rural U.S. Regions: Learning and Research Agenda; Harvard Business School, Institute for Strategy and Competitiveness: Cambridge, MA, USA, 2004.

31. Dabson, B. Rural-Urban Interdependence: Why Metropolitan and Rural America Need Each Other; The Brookings Institution, The Blueprint for American Prosperity Metropolitan Policy Program: Washington, DC, USA, 2007.

32. Dabson, B.; Johnson, R.; Miller, K.; Robinson, D. Rural-Urban Interdependence in Central Appalachia. Discussion Paper: Wealth Creation and Rural-Urban Linkages in Working Regions; Rural Policy Research Institute: Columbia, MO, USA, 2009.

33. Holland, D.; Lewin, P.; Sorte, B. The Declining economic interdependence of the Portland metropolitan core and its periphery. In Toward One Oregon: Rural-Urban Interdependence and the Evolution of a State; Hibbard, M., Seltzer, E., Weber, B., Emshoff, B., Eds.; Oregon State University Press: Corvallis, OR, USA, 2011; pp. 79-98.

34. Hughes, D.W.; Litz, V.N. Rural-urban economic linkages for agriculture and food processing in the Monroe, Louisiana, functional economic area. J. Agric. Appl. Econ. 1996, 28, 337-355. [CrossRef]

35. Lewin, P.; Weber, B.; Holland, D. Core-periphery dynamics in the Portland Oregon Region: 1982 to 2006. Ann. Reg. Sci. 2013, 51, 411-433. [CrossRef]

36. Searls, K. Pilot Study: Estimating Rural and Urban Minnesota's Interdependencies; Minnesota Rural Partners, Inc.: St Paul, MN, USA, 2011.

37. Waters, E.; Holland, D.; Weber, B. Interregional effects of reduced timber harvests: The impact of the Northern Spotted Owl listing in rural and urban Oregon. J. Agric. Resour. Econ. 1994, 19, 141-160.

38. U.S. Department of Agriculture (USDA). News Release no. 0142.15. 2015. Available online: http: / / www. usda.gov/wps/portal/usda/usdahome?contentid=2015/05/0142.xml (accessed on 1 March 2019).

39. U.S. Department of Agriculture, Rural Development (USDA RD). Rural Development: Seven Strategies for Economic Development. 2014. Available online: http://rurdev.sc.egov.usda.gov/RD_ EconomicDevelopment.html (accessed on 1 March 2019).

40. Vilsack, T. New Markets, New Opportunities: Strengthening Local Food Systems and Organic Agriculture. U.S. Department of Agriculture Results 2016. Available online: https:/ / medium.com/usda-results/newmarkets-new-opportunities-strengthening-local-food-systems-and-organic-agriculture-17b529c5ea90\# .81nvnyun7 (accessed on 1 March 2019).

41. National Sustainable Agriculture Coalition (NSAC). 2018 Farm Bill Drilldown: Local/Regional Food Systems, Rural Development. NSAC's Blog 2018. Available online: http:/ / sustainableagriculture.net/blog/2018farm-bill-drilldown-local-rural/ (accessed on 1 March 2019).

42. Jablonski, B.B.R. Farmers' markets as rural wealth creation. In Rural Wealth Creation; Pender, J., Johnson, R., Weber, B., Fannin, M., Eds.; Routledge: New York, NY, USA, 2014; Chapter 14; ISBN 978-0-41-585897-7.

43. Low, S.; Vogel, S. Direct and Intermediated Marketing of Local Foods in the United States; ERR-128; U.S. Department of Agriculture, Economic Research Service: Washington, DC, USA, 2011.

44. Low, S.; Adalja, A.; Beaulieu, E.; Key, N.; Martinez, S.; Melton, A.; Perez, A.; Ralston, K.; Stewart, H.; Clark, S.; et al. Trends in U.S. local and regional food systems: A report to Congress, AP-068; US Department of Agriculture, Economic Research Service: Washington, DC, USA, 2015.

45. Dimitri, C.; Oberholtzer, L.; Pressman, A. Urban agriculture: Connecting producers with consumers. Br. Food J. 2016, 118, 603-617. [CrossRef] 
46. U.S. Department of Agriculture, Agricultural Marketing Service (USDA AMS). Food Value Chains. Available online: https: / / www.ams.usda.gov/publications?field_term_program_tid=220 (accessed on 1 March 2019).

47. Nixon, P.A.; Ramaswami, A. Assessing current local capacity for agrifood production to meet household demand: Analyzing select food commodities across 377 U.S. metropolitan areas. Environ. Sci. Technol. 2018, 52, 10511-10521. [CrossRef] [PubMed]

48. Thilmany, D. What is driving consumer demand for local foods? In Agricultural Outlook Forum; No 126440; U.S. Department of Agriculture: Washington, DC, USA, 2012.

49. Hardesty, S.; Feenstra, G.; Visher, D.; Lerman, T.; Thilmany-McFadden, D.; Bauman, A.; Gillpatrick, T.; Rainbolt, G.N. Values-based supply chains: Supporting regional food and farms. Econ. Dev. Q. 2014, 28, 17-27. [CrossRef]

50. Schmit, T.M.; Jablonski, B.B.R.; Minner, J.; Kay, D.; Christensen, L. Rural wealth creation of intellectual capital from urban local food system initiatives: Developing indicators to assess change. Commun. Dev. 2017, 48, 639-656. [CrossRef]

51. Carolan, M. More-than-active food citizens: A longitudinal and comparative study of alternative and conventional eaters. Rural Sociol. 2017, 82, 197-225. [CrossRef]

52. Thilmany, D.; Bond, C.A.; Bond, J.K. Going local: Exploring consumer behavior and motivations for direct food purchases. Am. J. Agric. Econ. 2008, 90, 1303-1309. [CrossRef]

53. Jablonski, B.B.R.; Schmit, T.; Minner, J.; Kay, D. Rural Wealth Creation Impacts of Urban-Based Local Food System Initiatives: A Delphi Method Examination of the Impacts on Intellectual Capital; Charles, H., Ed.; Working Paper WP 2016-13; Dyson School of Applied Economics and Management, Cornell University: Ithaca, NY, USA, 2016.

54. Growing Food Connection. Local Government Food Policy Database, n.d. Available online: http:/ / growingfoodconnections.org/tools-resources/policy-database/ (accessed on 1 March 2019).

55. Johns Hopkins, Bloomberg School of Public Health. Food Policy Networks. Center for a Livable Future. n.d. Available online: https://www.jhsph.edu/research/centers-and-institutes/johns-hopkins-center-for-alivable-future/projects / FPN/ (accessed on 1 March 2019).

56. Georgiadis, P.; Vlachos, D.; Iakovou, E. A system dynamics modeling framework for the strategic supply chain management of food chains. J. Food Eng. 2005, 70, 351-364. [CrossRef]

57. Ilbery, B.; Maye, D. Food supply chains and sustainability: Evidence from specialist food producers in the Scottish/English borders. Land Use Policy 2005, 22, 331-344. [CrossRef]

58. Thilmany, D.; Jablonski, B.; Graff, G. Colorado Blueprint of Food and Agriculture. Colorado State University, 2017. Available online: Foodsystems.colostate.edu/research/colorado-blueprint (accessed on 1 March 2019).

59. Picanso, R.; Fretwell, L.; Vesey, T.; Post, P.; Gaynor, J.; Stebbins, E.; Hudson, C.; Cooper, J. Colorado Fruit Tree/Vineyard Survey 2002. National Agricultural Statistics Service, Colorado Agricultural Statistics Service, 2002. Available online: https://www.nass.usda.gov/Statistics_by_State/Colorado/Publications/Special_ Interest_Reports/2002-Fruit-Bulletin2.pdf. (accessed on 1 March 2019).

60. U.S. Department of Agriculture, Agricultural Research Service (USDA ARS). National Nutrient Database for Standard Reference. 2017a. Available online: https://www.ars.usda.gov/northeast-area/beltsvillemd-bhnrc/beltsville-human-nutrition-research-center/nutrient-data-laboratory / docs/usda-nationalnutrient-database-for-standard-reference/ (accessed on 1 March 2019).

61. U.S. Department of Agriculture, Agricultural Research Service (USDA ARS). 2017b. Food Patterns Equivalents Database. 2017b. Available online: https:/ / www.ars.usda.gov/northeast-area/beltsville-mdbhnrc/beltsville-human-nutrition-research-center/food-surveys-research-group/docs/fped-overview / (accessed on 1 March 2019).

62. U.S. Department of Agriculture, Economic Research Service (USDA ERS). U.S. Potato Statistics. 2017c. Available online: https://www.ers.usda.gov/topics/crops/vegetables-pulses/potatoes/ (accessed on 1 March 2019).

63. U.S. Department of Agriculture, National Agricultural Statistics Service (USDA NASS); Census of Agriculture: Washington, DC, USA, 2012.

64. U.S. Department of Agriculture, National Agricultural Statistics Service (USDA NASS). 2016 State Agriculture Overview: Colorado Crops-Planted, Harvested, Yield, Production, Price, Value of Production. 2016. Available online: https://www.nass.usda.gov/Quick_Stats/Ag_Overview/stateOverview.php?state= COLORADO (accessed on 1 March 2019). 
65. Hine, S.; Pritchett, J.; Meyer, S. San Luis Valley Potato Study; Agribusiness Marketing Report (ABMR) 03-01; Colorado State University: Fort Collins, CO, USA, 2003.

66. Kelley, K.M.; Primrose, R.; Crassweller, R.; Hayes, J.E.; Marini, R. Consumer peach preferences and purchasing behavior: A mixed methods study. J. Sci. Food Agric. 2016, 96, 2451-2461. [CrossRef]

67. Marzolo, G. Peaches. 2015. Available online: https://www.agmrc.org/commodities-products/fruits/ peaches (accessed on 1 March 2019).

68. Rettke, D. Colorado Potato Growers See Boom in Yellow Varieties. Fresh Plaza. 2017. Available online: http: / /www.freshplaza.com/article/182353/Colorado-potato-growers-see-boom-in-yellow-varieties (accessed on 1 March 2019).

69. Colorado Department of Agriculture (CDA). Farmers' Market Price Reports. 2015. Available online: https: / / www.colorado.gov/pacific/agmarkets/farmers-market-price-reports (accessed on 1 March 2019).

70. Thilmany, D.; Thomas, C. 2009. Farmers' Markets and Direct Marketing for Colorado Producers—4.007. 2009. Available online: http://extension.colostate.edu/topic-areas/agriculture/farmers-markets-anddirect-marketing-for-colorado-producers-4-007/ (accessed on 15 June 2018).

71. Costanigro, M.; Deselnicu, O.; McFadden, D.T. Product differentiation via corporate social responsibility: Consumer priorities and the mediating role of food labels. Agric. Hum. Values 2016, 33, 597-609. [CrossRef]

72. Umberger, W.J.; Thilmany McFadden, D.D.; Smith, A.R. Does altruism play a role in determining U.S. consumer preferences and willingness to pay for natural and regionally produced beef? Agribusiness 2009, 25, 268-285. [CrossRef]

73. Moser, R.R.; Thilmany-McFadden, D. Consumer preferences for fruit and vegetables with credence-based attributes: A review. Int. Food Agribus. Manag. Rev. 2011, 14, 121-141.

74. Tronstad, R.; Lev, L.; Nakamoto, S.; Bailey, D.V.; Bastian, C.; Curtis, K.; Lobo, R.; Umberger, W.; Ward, R. Certification and Labeling Considerations for Western Agricultural Producers; University of Arizona: Tuscon, AZ, USA, 2015.

75. Bauman, A.; Thilmany McFadden, D.; Jablonski, B.B.R. The financial performance implications of differential marketing strategies: Exploring farms that pursue local markets as a core competitive advantage. Agric. Resour. Econ. Rev. 2018, 47, 477-504. [CrossRef]

76. Spradley, J.P. Participant Observation; Holt, Rinehart and Winston: New York, NY, USA, 1980; ISBN 978-0-03-044501-9.

77. Center for Good Food Purchasing, n.d. Available online: https://goodfoodpurchasing.org/ (accessed on 1 March 2019).

78. Slee, R.W. From countrysides of production to countrysides of consumption? J. Agric. Sci. 2005, 143, 255. [CrossRef]

79. Woods, M. Rural Geography: Processes, Responses, and Experiences in Rural Restructuring; SAGE Publications: Thousand Oaks, CA, USA, 2005; ISBN 978-0-76-194760-8.

80. Campbell, M.C. Building a Common Table: The role of planning in community food systems. J. Plan. Educ. Res. 2004, 23, 341-355. [CrossRef]

81. Kloppenburg, J.J.; Lezberg, S.; DeMaster, K.; Stevenson, G.W.; Hendrickson, J. Tasting food, tasting sustainability: Defining the attributes of an alterative food system with competent, ordinary people. Hum. Organ. 2000, 59, 177-186. [CrossRef]

82. Hinrichs, C.C. The practice and politics of food system localization. J. Rural Stud. 2003, 19, 33-45. [CrossRef]

83. Gómez Tovar, L.; Martin, L.; Gómez Cruz, M.A.; Mutersbaugh, T. Certified organic agriculture in Mexico: Market connections and certification practices in large and small producers. J. Rural Stud. 2005, 21, 461-474. [CrossRef]

84. Jablonski, B.B.R.; Schmit, T.M.; Kay, D. Assessing the economic impacts of food hubs on regional economies: A framework that includes opportunity cost. Agric. Resour. Econ. Rev. 2016, 45, 143-172. [CrossRef]

85. Jablonski, B.; Perez-Burgos, J.; Gómez, M. Food value chain development in central New York: CNY bounty. J. Agric. Food Syst. Commun. Dev. 2011, 129-141. [CrossRef]

86. Myers, J.S.; Sbicca, J. Bridging good food and good jobs: From secession to confrontation within alternative food movement politics. Geoforum 2015, 61, 17-26. [CrossRef] 
87. Graf, K.; Cohen, A.; Miller, B.S.; Vaghi, F. Re-examining the contested good: Proceedings from a postgraduate workshop on good food. Gastronomica 2019, 19, 91-93. [CrossRef]

88. Pilgeram, R.; Meeuf, R. Good food, good intentions: Where pro-sustainability arguments get stale in US food documentaries. J. Environ. Commun. 2015, 9, 100-117. [CrossRef] 